\title{
A Comparison with Analysis of the SADC FIP before and after Its Amendment
}

\section{T Kondo*}

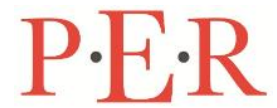

Pioneer in peer-reviewed, open access online law publications

Author

Tinashe Kondo

Affiliation

University of Western Cape South Africa

Email tkondo@uwc.ac.za

Date published

25 August 2017

\section{Editor Prof W Erlank}

How to cite this article

Kondo T "A Comparison with Analysis of the SADC FIP before and after Its Amendment "PER / PELJ 2017(20) - DOI http://dx.doi.org/10.17159/17273781/2017/v20i0a1676

\section{Copyright}

\section{(i)}

DOI

http://dx.doi.org/10.17159/17273781/2017/v20i0a1676

\section{Abstract}

Discourses on rights, duties and obligations predominantly take place within the context of constitutional, administrative and human rights law. In the last decade these debates have also begun to take place in international investment law, an "autonomous branch" of international law. The main debate centres on the adequacy and sustainability of investor-centred regulatory regimes which provide more rights than obligations to investors. The 2006 Southern African Development Community Finance and Investment Protocol (SADC FIP) was a typical example of such a regime. It offered antiquated protections which were characteristic of first generation Bilateral Investment Treaties (BITs). The result was that some countries, such as South Africa, opted not to conform to this binding instrument, which did not match their progressive vision of foreign investment. It is against this backdrop that the SADC FIP was recently amended. The amendment, balances the rights and obligations of investors and state parties to some degree, and moves towards sustainable foreign investment. However, this paper argues that more still needs to be done to modernise the document in line with more recent trends.

\section{Keywords}

Foreign investment; rights; obligations; investors; State Parties; sustainable development; policy space; the right to regulate; SADC FIP. 


\section{Introduction}

The end of the Second World War (WW2) paved the way for a new era built on the principle of international co-operation. ${ }^{1}$ Over time this co-operation would take specific forms such as the United Nations (UN) and the European Coal and Steel Community (the modern-day European Union). ${ }^{2}$ On the legal front, international law evolved from functioning mainly as a tool for mutual deterrence to an instrument promoting co-operation and coordination. ${ }^{3}$ In the context of international trade, apart from the emergence of new global governance institutions such as the World Trade Organisation (WTO), this era witnessed the signing of treaties such as the General Agreement of Trade and Tariffs (GATT) and the General Agreement on Trade in Services (GATS).

Among the more prominent agreements to grace the international trade scene are regional trade agreements (RTAs). Some RTAs are special in that they not only deal with the issue of integrating trade, but they also cover investment regulation. ${ }^{4}$ This is important because of the symbiotic relationship between trade and investment. ${ }^{5}$ As these instruments address key issues, they have multiplied across the globe.

In Southern Africa, the Southern African Development Community (SADC) is the most prominent regional organisation. This organisation was developed in terms of the Southern African Development Community Treaty (SADC Treaty), with the purpose inter-alia of promoting the free flow of capital through improving the investment climate and enhancing cooperation. ${ }^{6}$

Tinashe Kondo. BCom LLB LLM (University of the Western Cape). LLD candidate, University of the Western Cape. Associate Lecturer, Mercantile Law Department, University of the Western Cape. Email: tkondo@uwc.ac.za. I acknowledge the input of Nyasha Noreen Katsenga, Obdiah Mawodza and Bethsheba Kangwa, who provided helpful comments. Special thanks are also extended to the two peer reviewers who provided insightful feedback.

McGowan, Cornelissen and Nel Power, Wealth and Global Equity 152.

OECD International Regulatory Co-operation 65-66.

Laos Foundations of Cultural Diplomacy 17.

Gazzini and Brabandere International Investment Law 61.

As noted by Price, "trade and investment flows are interdependent". See Price 1993 Int'l Law 727.

6 Preamble of the SADC Treaty. The SADC consists of 15 Member States, namely: Angola, Botswana, the Democratic Republic of Congo (DRC), Lesotho, Madagascar, Malawi, Mauritius, Mozambique, Namibia, Seychelles, South Africa, Swaziland, the United Republic of Tanzania, Zambia and Zimbabwe. 
Foreign investment in the SADC region is regulated under the SADC FIP. ${ }^{7}$ This is a legally binding and internationally recognised document that creates rights and obligations for all Member States and investors. ${ }^{8}$ The investor rights established in this document are of an international nature and cannot be unilaterally amended at a domestic level. ${ }^{9}$

In recent times the SADC FIP has been amended, giving rise to interesting discussions on the contents of the document. It is against this background that this article evaluates the efficacy of these changes. The paper argues that, for the most part, the changes made to the SADC FIP are vital in balancing the rights and obligations of investors and host states. However, the article adopts the view that more still needs to be done in order to align the contents of the document with best practice.

The article is structured as follows. Firstly, the practical challenges of the 2006 SADC FIP are furnished. Secondly, an analytic comparison of the key provisions in the 2006 SADC FIP and the 2016 SADC FIP is made. Finally, the key issues are summarised and the findings are furnished. The paper suggests that: (1) the definition of investors in the 2006 SADC FIP be readopted; (2) the fair and equitable clause be returned, albeit in a qualified form, (3) the transparency clause be extended to investors and their home States; (4) the optimal use of natural resources clause be aligned to sustainable development; (5) investor-state arbitration be re-introduced, but as an option of last resort after all domestic avenues have been exhausted; (6) the investor liability clause be expanded; and (7) a clause on physical security be introduced.

\section{Practical challenges of the 2006 SADC FIP}

The fast pace of international investment law constantly requires investment policies to adapt and accommodate newer trends. For example, in the 1960s it was necessary for an investment regime to be based largely on BITs. Not so long after it was also important for a state to conclude Regional Trade and Investment Agreements (RTIAs) which focus on regional integration and economic growth. Today, in addition to BITs and RTIAs, states also have to conclude investment contracts and create domestic investment codes making provision for laws relating to foreign investments.

7 All Member States signed the SADC FIP in 2006. It was subsequently ratified in 2010 by a two-thirds majority.

$8 \quad$ The SADC FIP gives practical implementation to the SADC Treaty.

9 Trade and Investment Parliamentary Committee 2015 http://pmg-assets.s3-websiteeu-west-1.amazonaws.com/150922Summary_of_Matrix.pdf. 
The content of these investment policies is equally vital. This is because most investment provisions are biased in favour of the investor and restrict policy space for the host-state. ${ }^{10}$ This is especially true in the case of first generation BITs, which provide for investor protection without investor obligations and also lack policy space for the host-state. ${ }^{11}$ The effect of this in some cases is that the host state is exposed to large claims when it attempts to implement domestic measures in conflict with the biased investment provisions. ${ }^{12}$

The 2006 SADC FIP was based on first-generation BITs which have outlived their usefulness. These BITs provide more investor rights than they provide investor obligations or the rights of the state. The effect was that the 2006 SADC FIP contained less policy space for domestic states. In recent times the need for policy space has taken centre stage. Many countries such as South Africa, India and Australia are now focussing on having socially responsive investment regimes which can advance the agenda of sustainable development. ${ }^{13}$ The SADC FIP had been lacking in this regard, to a degree.

While the 2006 SADC FIP provided for enlightened clauses such as corporate responsibility, the optimal use of national resources, environmental measures and the right to regulate, this had still been far from what is anticipated in newer international investment agreements (IIAs). As an example, the Southern African Development Community Model Bilateral Investment Treaty (SADC Model BIT) also includes more progressive provisions such as the right of the state to pursue developmental goals ${ }^{14}$ and the minimum standards for human rights, the environment and labour. ${ }^{15}$ Although the 2006 SADC FIP touched on some of these concepts, they

$10 \quad$ Grear and Kotzé Research Handbook on Human Rights and the Environment 493.

11 Skovgaard Poulsen Bounded Rationality and Economic Diplomacy 89.

12 Up to 2014 , a total of 608 cases had been brought for investor-state dispute settlement (ISDS). Of these $43 \%$ were decided in favour of the host state, $31 \%$ in favour of the investor and 27\% were settled. See EFILA 2015 http://efila.org/wpcontent/uploads/2015/05/EFILA_in_response_to_the-

criticism_of_ISDS_final_draft.pdf.

13 South Africa has enacted the Protection of Investment Act 22 of 2015, which is expected to come into force towards the end of 2017. It has also served notices to terminate most of its existing BITs. India is also moving to terminate its existing BITs and has already sent notifications to this effect. For those treaties that are expiring, India has requested the other parties to renegotiate so as to clarify existing ambiguities. India also released a new Model BIT in 2015, which will serve as the basis for future negotiations. Australia has made a hard exit out of the ISDS system. All future BITs and RTIAs it engages in will no longer include investor-state arbitration.

14 Article 21 of the SADC Model BIT.

15 Article 15 of the SADC Model BIT. 
were not put forward expressly. ${ }^{16}$ It provided generic rights and obligations as opposed to future-looking balanced rights and obligations.

As a result, some states (such as South Africa) chose to apply the SADC Model BIT in the development of their domestic laws, despite their constitutional and international obligations to honour the commitments in the SADC FIP. Woolfery asserts that the 2006 SADC FIP was inconsistent with the more favourable SADC Model BIT. ${ }^{17}$ This was because, as discussed earlier, it contained a number of BIT-style provisions which were inconsistent with the SADC Model BIT. ${ }^{18}$ For instance, the SADC Model BIT recommends against the inclusion of a provision on fair and equitable treatment and opts instead for an alternative formulation of the provision on fair administrative treatment, if it is deemed necessary to include this clause. ${ }^{19}$

Further to the above, Member States were unclear about their commitments derived from the SADC FIP and their legal implications. According to the SADC FIP Baseline Project Report prepared by the Finmark Trust, only $53.4 \%$ of the country-level commitments of the FIP had been realised. ${ }^{20}$

As a result of the challenges of the 2006 SADC FIP, there was therefore a need to amend the document. ${ }^{21}$ A new SADC FIP was tabled to the Council of Ministers and adopted on the $14^{\text {th }}$ of August 2015. The parties signed to these changes on the $31^{\text {st }}$ of August 2016. ${ }^{22}$ This document is now in force but was released to the public only on the $16^{\text {th }}$ of May $2017 .^{23}$

16 See the commentary on art 21 of the SADC FIP.

17 Woolfrey 2014 https://www.tralac.org/discussions/article/5358-is-an-overhaul-ofthe-sadc-protocol-on-finance-and-investment-imminent.html.

18 Woolfrey $2014 \mathrm{https}: / / \mathrm{www}$.tralac.org/discussions/article/5358-is-an-overhaul-ofthe-sadc-protocol-on-finance-and-investment-imminent.html.

19 Article 5 of the SADC Model BIT.

20 SADC, GIZ and Finmark Trust 2011 http://www.finmark.org.za/sites//wpcontent/uploads/pubs/Broch_FIP0312.pdf. Of the remaining percentage, $8.4 \%$ represents commitments in the process of being realised, while the rest remains unrealised. It is important to note the disclaimer that this study is based on desktop research.

21 The new FIP was tabled to the Council of Ministers at the end of 2015. The new FIP contains newer trends such as state-state arbitration and moves away from the problematic provisions in the old FIP, which were based on old-generation BITs. See Trade and Investment Parliamentary Committee 2015 http://pmg-assets.s3-websiteeu-west-1.amazonaws.com/150922Summary_of_Matrix.pdf.

The amendments required the adoption by three-quarters of the Member States that are a party to the SADC FIP. Such adoption has already taken place. This information was supplied and confirmed in an email by Shubi Mukarasi and Thembi Langa from the SADC. operation on Investment) of the Protocol on Finance and Investment (2015). 
The next section of this article critically assesses the differences between the 2006 SADC FIP and the 2015 SADC FIP. In doing so, the positives and short-comings of such changes are discussed. As will be noted in that section, many of the changes were those proposed by South Africa. These were on limiting the definition of investment, elaborating on the determination of the value of a property on expropriation, clarifying the text to provide for a clear and substantive provision on national treatment, redefining the right to regulate, and removing international arbitration as a measure for resolving investor-state disputes. ${ }^{24}$

\section{An analytic comparison of the 2006 SADC FIP and the 2016 SADC FIP}

\subsection{Common provisions: the definition of "investors" and "investments"}

In most International Investment Agreements (IIAs), the definitions clause is an important provision. ${ }^{25}$ It usually contains essential definitions that define the application of the treaty. This has important implications for the host state. For instance, the United Nations Conference on Trade and Development (UNCTAD) notes that how these definitions are given has an impact on a country's potential exposure to investor-state claims. ${ }^{26}$ This has seen recent agreements attempting to restrict the scope of these definitions, so as to limit the risk of claims from investors. At the centre of this debate have been two key definitions: "investment" and "investor".27 These definitions will now be discussed in the context of the SADC FIP. ${ }^{28}$

When defining an investor, three options are generally employed. These are an enterprise-based definition, a closed-list asset-based definition, and an open-list asset-based definition. The significance of which definition is employed in a treaty relates to the scope of the provision. ${ }^{29}$ These definitions will now be presented from the most narrowly drafted to the most broadly drafted.

An enterprise-based definition is the narrowest option for defining an investment. It requires the establishment or acquisition of an enterprise for

\footnotetext{
24 PMG 2016 http://pmg.org.za/files/150922summary.pdf.

25 Horn Arbitrating Foreign Investment Disputes 201.

26 UNCTAD 2012 http://unctad.org/en/Docs/unctaddiaeia2011d5_en.pdf xi.

27 See generally Gwynn Power in the International Investment Framework 92.

28 While one could also discuss the temporal and geographic scope, the main debate has been about the assets and persons which find protection under an agreement. 
the purpose of making a foreign investment. ${ }^{30}$ The definition then lists the assets of the investor that are covered because they form part of the enterprise. This illustrative list is not the test for investment, however, but rather an illustration of the types of assets of the investor which are covered by the treaty. ${ }^{31}$

A closed-list asset-based definition is an intermediate approach to defining an investment. This definition is similar to the enterprise-based definition in part. This is because when it was developed it was envisaged as an enterprise-based definition in the United States-Canada Free Trade Agreement (NAFTA). ${ }^{32}$ Over time, however, the definition evolved into its current form as reflected in Article 1139 of NAFTA and recent BITs. It now provides a closed list which "starts from an enterprise approach, but expands this to include assets such as intellectual property rights, whether or not they are associated with an existing enterprise in the Host State". ${ }^{33}$

An open-list asset-based definition provides for the broadest coverage. The definition is characterised by the use of broad language such as "every kind of asset" or "every kind of investment", followed by a non-exhaustive list of the investments covered. ${ }^{34}$ This approach is more favourable to investors and less predictable for host states. ${ }^{35}$ This is because arbitral tribunals can interpret this definition widely to include assets not usually considered to be investments. ${ }^{36}$ The lack of limitations in this definition is therefore its biggest challenge. ${ }^{37}$ Notwithstanding, this has been the most widely adopted definition in first-generation BITs. ${ }^{38}$

The 2006 SADC FIP provided for a wide definition of investment. This was attributed to the open-list asset-based definition of investment that was furnished in the document. The result was that most assets were covered

\footnotetext{
30 Commentary of art 2 of the SADC Model BIT.

31 Commentary of art 2 of the SADC Model BIT.

32 UNCTAD 2007 http://unctad.org/en/docs/iteiia20065_en.pdf.

33 Commentary of art 2 of the SADC Model BIT.

34 Legum 2005 https://www.oecd.org/investment/internationalinvestmentagreements/ 36370461.pdf.

35 Commentary of art 2 of the SADC Model BIT.

36 Van Duzer, Simons and Mayeda Integrating Sustainable Development 50. Also see Tabari Lex Petrolea and International Investment Law 105.

It is important to note that in some BITs, however, investments have been limited to those made in accordance with the domestic law of the host state or those that have been duly registered in the host state. See Dunning and Gugler Foreign Direct Investment 252. 
as investments. This definition has been widely used in most SADC BITs. ${ }^{39}$ For example, the Zimbabwe-Netherlands BIT provides a definition that includes the wording "every kind of asset". 40 This is in contrast to the narrower definitions, such as the closed-list asset-based definition ${ }^{41}$ and the enterprise-based definition, which could have been used in the alternative. ${ }^{42}$

The 2016 SADC FIP resolves this challenge. An enterprise-based definition proposed by South Africa replaces the open-list asset-based definition. ${ }^{43}$ The provision is drawn almost verbatim from the enterprise-based definition in the SADC Model BIT.44 It defines investment as an enterprise established, acquired or expanded by an investor of one state party in the territory of another state party. ${ }^{45}$ A non-exhaustive list of assets of the enterprise is also provided. The importance of this definition is that it reduces the scope of the previous definition and increases precision by covering assets only when they are part of the assets of an enterprise. ${ }^{46}$ This precision is important in the developing country context of the SADC, where the thrust should be towards sustainable development and investment.

Similarly, "investor" was widely defined in the 2006 SADC FIP. An investor is classified as "a person that has been admitted to make or has made an investment". ${ }^{47}$ Herein, a person is defined as a natural or juristic person. ${ }^{48}$ The implication of this definition was that even investors from countries other than those of the State Parties were covered by the 2006 SADC FIP as long as they had been admitted to make an investment or had made an investment. Furthermore, the definition left some important issues unresolved. For instance, it did not address the issue of natural persons who have dual citizenship or companies that are not in effect managed in the

See the commentary on art 2 of the SADC Model BIT. Investors tend to prefer an asset-based definition as it affords them wider protection. Article 1(1) of the Agreement on Encouragement and Reciprocal Protection of
Investments between the Republic of Zimbabwe and the Kingdom of the Netherlands (1996) (Zimbabwe-Netherlands BIT). The asset-based definition provides a closed list of assets which can be deemed as investments. The enterprise-based definition is the narrowest definition detailing the assets which may be owned by an enterprise. See the commentary on art 2 of the SADC Model BIT for a detailed discussion. PMG 2016 http://pmg.org.za/files/150922summary.pdf.

Article 2 of the SADC Model BIT.

Article 1 of the 2016 SADC FIP.

46 For the most part, the assets covered in the enterprise-based definition are similar to those covered in an open-list asset-based definition.

47 Article 1 of Annex 1 of the 2006 SADC FIP. 
country of incorporation. This created uncertainties as to whether these dual citizens or companies effectively managed in another country could be classified as investors.

The 2016 SADC FIP narrows the definition of an investor. An investor is viewed only as "a natural or a juridical person of another State Party, in accordance with the laws and regulations of the State Party in which the investment is made". ${ }^{49}$ This means that investors who do not originate from a SADC country are no longer covered under the SADC FIP. The new investor definition limits the usefulness of the SADC FIP. This is because for the most part investment in the SADC comes from investors from other countries rather than from SADC investors. ${ }^{50}$ As a result, the SADC FIP, extends protection to the investors who least need it. In addition, the definition also goes against the recommendation by South Africa that all foreign investments from any state be covered, subject to the condition that a dispute between an investor and a member state be adjudicated in terms of the domestic law of such a state. ${ }^{51}$ Furthermore, the definition does not resolve outstanding issues in the previous definition on the treatment of dual nationals and companies managed in effect in other jurisdictions.

\subsection{Investor rights post-establishment}

\subsubsection{Treatment}

Non-discrimination has become one of the key protections afforded to investors in the treaty system. The general thrust of this principle is that states cannot discriminate among investors on the basis of their nationality. ${ }^{52}$ In international investment law, non-discrimination is often exemplified in the national treatment and most-favoured nation (MFN) treatment standards..$^{53}$ These treatment standards will now be discussed.

A standard provision of MFN treatment was provided for in the 2006 SADC FIP. ${ }^{54}$ It stated that foreign investors may be afforded no less favourable treatment than that which is accorded investors of any other third state. ${ }^{55}$ The practical consequence of the clause was that it placed investors from different countries in a host state on the same level. This is, however,

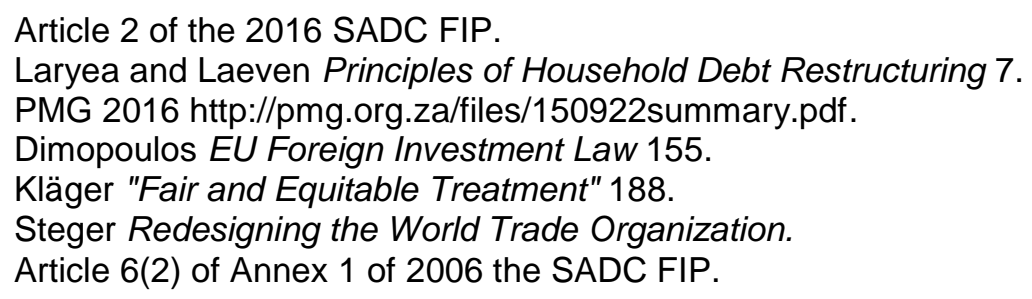


subject to the exceptions in Article 7(1) of Annex 1 of the 2006 SADC FIP. 56 Notably, however, the 2006 SADC FIP did not clarify whether MFN treatment is applicable to both pre-establishment and post-establishment. This was important as it would determine what rights are afforded to investors.

The 2016 SADC FIP does not contain an MFN clause. This is in line with the recommendation by South Africa that the MFN clause be replaced by a more substantive national treatment clause. ${ }^{57}$ While the MFN clause was important because it prevented distortions from country-country liberalisation ${ }^{58}$ and also guarded against poor draftsmanship, it also brought with it challenges. For instance, it was not clear how the MFN clause should be interpreted or how far its obligations extended. As a case in point, one can note the vagueness on the issue of whether or not the MFN clause could be interpreted as applying to dispute settlement. ${ }^{59}$ Furthermore, the MFN clause allowed investors to capture benefits granted to other investors in other treaties in a manner that was not envisaged by the host state. ${ }^{60}$ Herein, foreign investors could incorporate more generous clauses or stronger commitments than are found in other treaties. ${ }^{61}$ This allowed in a manner for "treaty shopping" and "free riding", where investors receive unearned benefits, which in turn unseats the idea of reciprocal concessions. ${ }^{62}$ The MFN clause therefore had the unintended consequence of subverting the will of the contracting parties in a manner that altered the substance of the treaty. ${ }^{63}$ There was therefore a compelling case to omit the MFN clause, regardless of its benefits. This is also consistent with the

56 Notably, the SADC FIP does not clarify whether MFN treatment is applicable to both pre-establishment and post-establishment. This is important as it determines what rights are afforded to investors.

57 PMG 2016 http://pmg.org.za/files/150922summary.pdf.

$58 \quad$ Flodgren Corporate and Employment Perspectives 70.

$59 \quad$ Tanzi et al International Investment Law in Latin America 202.

$60 \quad$ Collins Introduction to International Investment Law 110.

61 See Asian Agricultural Products Ltd v Sri Lanka ICSID Case No ARB/87/3; Pope and Talbot v Canada, UNCITRAL; Maffezini $v$ Spain ICSID Case No ARB/97/7; ADF $v$ USA ICSID Case No ARB(AF)/00/1 of 9 January 2003; Tecmed $v$ Mexico ICSID Case No ARB (AF)/00/2 of 29 May 2003; The Loewen Group Inc, Raymond L Loewen $v$ The United States of America ICSID Case No ARB(AF)/98/3 26 June 2003; Yaung Chi Oo (YCO) Trading Pte Ltd v Myanmar ASEAN ID Case No ARB/01/1 31 March 2003; MTD v Chile ICSID Case No ARB/01/7 25 May 2004; Siemens $v$ Argentina ICSID Case No ARB/02/8 of 3 August 2004. 
recommendation of the SADC Model BIT that the MFN treaty should not be included in a treaty as it has the unintended effect of multilaterisation. ${ }^{64}$

Surprisingly, the 2006 SADC FIP did not provide for national treatment, one of the most shared standards. ${ }^{65}$ The national treatment standard provides that a host state should not give a foreign investor treatment less favourable than that afforded to a domestic investor (in "like circumstances"). ${ }^{66}$ The standard, therefore, guards against protectionism by preventing discrimination on the basis of nationality. ${ }^{67}$ While it can be advanced that excluding national treatment from the 2006 SADC FIP, as has been done in some BITs, ${ }^{68}$ would allow Member States to be able to regulate issues such as labour, health and the environment, this could still be done through providing exceptions and qualifications. ${ }^{69}$ For example, the SADC Model $\mathrm{BIT}^{70}$ provides that states can impose special exceptions such as those ensuring that foreign investments are legally constituted under domestic law. ${ }^{71}$ Such a provision balances investor protection and the right to regulate.

The 2016 SADC FIP remedies the challenges of the 2006 SADC FIP by including a substantive national treatment clause. In addition to defining the treatment that should be given, ${ }^{72}$ the clause further elaborates on what constitutes "like circumstances" and furnishes an indicative list of factors to consider in deciding the likeness of the circumstances. ${ }^{73}$ More importantly, the national treatment standard in the 2016 SADC FIP has been qualified. Article $6(3)$ of the 2016 SADC FIP provides that notwithstanding the

64 Commentary on art 5 of the SADC Model BIT.

65 Schill International Investment Law 244.

66 See, for example art 4(2) of the Agreement between the Swiss Confederation and the Republic of Botswana on the Promotion and Reciprocal Protection of Investments (1998) (Botswana-Switzerland BIT); art 3(1) of the Federal Republic of Germany and Lesotho Treaty Concerning the Encouragement and Reciprocal Protection of Investment (with Protocol) (1982) (Lesotho-Germany BIT); art 3(2) of the Agreement between the Government of the United Kingdom of Great Britain and Northern Ireland and the Government of the Kingdom of Swaziland for the Promotion and Protection of Investments (1995) (Swaziland-United Kingdom BIT). Other BITs have gone as far as adding the words "like circumstances" to ensure that the national treatment can be provided in comparable settings. Also see art 1102 of North American Free Trade Agreement (1994) (NAFTA); Van Duzer, Simons and Mayeda Integrating Sustainable Development 120; Reinisch Standards of Investment Protection 38.

67 See Salacuse Law of Investment Treaties 274.

68 Sacerdoti et al General Interests of Host States 405.

$69 \quad$ Solanes and Jouravlev Revisiting Privatisation 34.

70 The SADC Model BIT opts to include national treatment rather than MFN treatment.

71 Article 4(5) of the SADC Model BIT.

72 Article 6(1) of the 2016 SADC FIP.

73 See art 6(2) of the 2016 SADC FIP. 
obligation to provide national treatment, a state party may, in accordance with its domestic legislation, grant preferential treatment to domestic investors and investments in order to achieve developmental objectives.

This clause is particularly important given the development needs of developing countries as well as the constitutional imperatives and mandates of some of the Member States. For example, the Zimbabwean and South African Constitutions focus on redressing the injustices of the past by empowering previously disenfranchised groups through preferential treatment. ${ }^{74}$ This has been reflected in Zimbabwe's Indigenisation and Economic Empowerment Act [Chapter 14: 30] (IEEA) and South Africa's Broad-Based Black Economic Empowerment Act 53 of 2003 (BEE Act). ${ }^{75}$ As a result, these countries have incorporated this idea in the drafting of their recent treaties. For instance, the 2009 Zimbabwe-South Africa BIT provides a qualified national treatment standard. ${ }^{76}$ This provision inter alia notes that a state party shall not be in breach of the national treatment obligation if its laws or measures are designed to promote the achievement of equality within its territory or are designed to advance or protect persons or categories of persons who have been disadvantaged by unfair discrimination in its territory. ${ }^{77}$ It is therefore not surprising that South Africa recommended the inclusion of the national treatment provision in the 2016

74 See, for example, s 9(2) of the Constitution of the Republic of South Africa, 1996 and s 14 of the Constitution of the Republic of Zimbabwe, 2013.

75 The Indigenisation and Economic Empowerment Act [Chapter 14: 30] (IEEA) requires all companies to cede $51 \%$ of the shareholding of their companies to indigenous Zimbabweans. The IEEA also requires that $51 \%$ of all the goods purchased by the Government in terms of the Procurement Act [Chapter 22: 14] be from companies where a controlling interest is held by indigenous Zimbabweans. See s 3(1)(a) of the IEEA. See further Statutory Instrument 21 of 2010 in GG Extraordinary of 29 January 2010, Statutory Instrument 34 of 2011 in GG Extraordinary of 25 March 2011, Statutory Instrument 84 of 2011 in GG Extraordinary of 27 July 2011, Statutory Instrument 114 of 2011 in GG Extraordinary of 25 March 2011, Statutory Instrument 66 of 2013 in GG of 17 March 2013. The Broad-Based Black Economic Empowerment Act 53 of 2003 (BEE Act) focuses on, but is not limited to: "increasing the number of black people that manage, own and control enterprises and productive assets; facilitating ownership and management of enterprises and productive assets by communities, workers, cooperatives and other collective enterprises; human resource and skills development; achieving representation in all occupational categories and levels in the workforce; preferential procurement and investment in enterprises that are owned or managed by black people". See s 1 of the BEE Act.

76 Article 3 of the Agreement between the Government of the Republic of South Africa and the Government of the Republic of Zimbabwe for the Promotion and Reciprocal Protection of Investments (2009).

77 Article 3(4) of the Agreement between the Government of the Republic of South Africa and the Government of the Republic of Zimbabwe for the Promotion and Reciprocal Protection of Investments (2009). 
SADC FIP, which bears a striking resemblance to Article 8 of the South African Protection of Investment Act 22 of 2015. In addition, the provision also draws from Article 4 of the SADC Model BIT on non-discrimination.

\subsubsection{Investor protection}

The protection standards in IIAs are perhaps the standards most keenly followed by foreign investors. The reason for this is that investors want to ascertain how much protection is available to their investments. ${ }^{78}$ As a result, this section details the various protections that are contained in the 2016 SADC FIP. These are compared with previous protections under the 2006 SADC FIP and discussed under the following headings: (1) expropriation and compensation (2) fair and equitable treatment and (3) the repatriation of funds and transfer of profits.

\subsubsection{Expropriation and compensation}

The right to expropriate in customary international law is a jealously guarded right. ${ }^{79}$ Generally, such expropriation should take place in the interest of the public or for a public purpose. As noted by Brown, the universal view under customary international law is that:

For expropriation to be lawful, the taking must be made in the public interest, on a non-discriminatory basis, under due process of law, and provision must be made for prompt, effective and adequate compensation. ${ }^{80}$

Over time, this universal view developed into the "Hull doctrine" after a letter by Cordell Hull, the then Secretary of State of the United States of America, ${ }^{81}$ to Mexico, detailing that it is accepted practice that expropriation must be followed by the payment of "prompt, effective and adequate compensation". ${ }^{82}$ Such compensation had to be complete and paid at a market value. ${ }^{83}$ However, today there is no general consensus as to what compensation should be payable. ${ }^{84}$ It was said in CME v Czech Republic,

78 Bosman 2016 https://www.ekon.sun.ac.za/wpapers/2016/wp042016/wp-04-2016. pdf.

79 OECD Investment Policy Reviews: Jordan 2013102.

80 Brown Commentaries on Selected Model Investment Treaties 677; Agreement between the Republic of Colombia and the Swiss Confederation on the Promotion and Reciprocal Protection of Investments (2006) (Switzerland-Colombia BIT).

81 Wellhausen Shield of Nationality 201.

82 Hackworth Digest of International Law 657.

83 Brown Commentaries on Selected Model Investment Treaties 677.

84 See ADC v Hungary ICSID Case No ARB/03/16 of 2 October 2006; Germany $v$ Poland (1928) PCIJ, Ser A, No 17 of 13 September 1928. 
however, that despite the divergent views on what compensation is payable, full compensation should be paid. ${ }^{85}$

The 2006 SADC FIP guaranteed investors a Hull-based protection where expropriation is done for a public purpose (or in the public interest). This is espoused in Article 5 of Annex 1 of the 2006 SADC FIP, which states:

Investments shall not be nationalised or expropriated in the territory of any State party except for a public purpose, under due process of the law, on a non-discriminatory basis and subject to the payment of prompt, adequate and effective compensation. ${ }^{86}$

The approach taken by the 2006 SADC FIP with respect to expropriation was consistent with the property clauses in domestic constitutions as well as expropriation clauses in the current BITs of the Member States.

For instance, the new Zimbabwean Constitution provides in section 71(3) that persons may be compulsorily deprived of their property only if the deprivation is done: "in terms of law of general application; in the interests of defence, public safety, public order, public morality, public health or town and country planning; or in order to develop or use that or any other property for a purpose beneficial to the community". ${ }^{87}$ Furthermore, section 71(3)(c) requires the acquiring authority to give reasonable notice, pay fair and adequate compensation before acquiring the property or within a reasonable time after the acquisition, and approach a competent court for a confirmation order 30 days before or after the property was acquired, if the acquisition is disputed.

The South African Constitution, as another example, provides in section 25 that no persons may be arbitrarily deprived of their property unless in terms of law of general application. ${ }^{88}$ When such a law is followed, this must be for a public purpose or in the public interest and subject to the payment of compensation determined by the affected parties or a court of law. Further, the "amount of compensation and the time and manner of payment must be just and equitable, reflecting an equitable balance between the public interests of those affected and all the relevant circumstances". 89

85 CME v Czech Republic (UNCITRAL) 9 ICSID Reports 121 of 13 September 2001 para 497.

86 Article 5 of Annex 1 of the SADC FIP.

87 Section 71(3)(a)-(b) of the Constitution of the Republic of Zimbabwe, 2013. This section provides for protection from expropriation.

88 Section 25(1) of the Constitution of the Republic of South Africa, 1996.

89 These circumstances include: "the current use of the property; the history of the acquisition and use of the property; the market value of the property; the extent of 
In both examples, despite the variable language used, expropriation must be done in accordance with law of general application. In addition, it must be for a public purpose or in the public interest, and prompt, effective and adequate compensation must be given. While the expropriation clause in the 2006 SADC FIP covered a fair number of the important issues regarding expropriation despite its brevity, more detail could have been given.

The 2016 SADC FIP deals with expropriation and nationalisation in more detail and in a slightly different manner. ${ }^{90}$ Firstly, in terms of compensation, the 2016 SADC FIP does not utilise the Hull formula (fair, prompt and adequate compensation). Instead it provides that expropriation or nationalisation should be done subject to the payment of fair and adequate compensation. This is in line with the formulation in Article 6(1) of the SADC Model BIT. The provision then goes on to clarify the determination of fair and adequate compensation. It notes that:

Fair and adequate compensation shall be assessed in relation to the fair market value of the expropriated investment immediately before the expropriation took place ("date of expropriation") and shall not reflect any change in value occurring because the intended expropriation had become known earlier. However, where appropriate, the assessment of fair and adequate compensation shall be based on an equitable balance between the public interest and the interest of those affected, having regard to all relevant circumstances and taking account of:
(a) the current and past use of the property;
(b) the history of its acquisition;
(c) the fair market value of the investment;
(d) the purpose of the expropriation;
(e) the extent of the previous profit made by the foreign investor through the investment; and
(f) the duration of the investment.

This is consistent with the second proposal by South Africa, that there be more flexibility with regards to the valuation of the expropriated investment. ${ }^{91}$ South Africa further proposed that the standard of compensation contemplated in section 25 of the South African Constitution be applied. A comparison of Article 5 of Appendix 1 of the 2016 SADC Model

direct state investment and subsidy in the acquisition and beneficial capital improvement of the property; and the purpose of the expropriation". See s 25(3) of the Constitution of South Africa, 1996.

90 See art 5 of the 2016 SADC FIP. South Africa's first proposal was more in line with option 2 of art 6(2) of the SADC Model BIT. This approach envisages that fair market value should be the point of departure when it comes to the quantification of compensation, but this should not be the definitive standard. Rather, where possible, the host state should be able to use an alternative valuation which is fairer to all parties. 
BIT and section 25(3) of the South African Constitution reveals that the former is derived from the latter. This is in line with option 1 for Article 6(2) of the SADC Model BIT. This approach reflects a sober and more balanced approach to determining compensation because it strikes a balance between the public interest and the interests of those affected. The reason for this is that while there is a presumption that the fair market value will be used, a state can still rebut this presumption on the basis of the equitable criteria set out in the provision. ${ }^{92}$

Second, the 2016 SADC FIP provides for the manner in which the compensation must be given. It states that the payment shall be made in a freely convertible currency in accordance with the applicable law of the host state..$^{93}$ Third, the investor is given a right under domestic law to challenge the expropriation or the valuation of the compensation awarded. ${ }^{94}$ This can be done by means of a judicial review or by means of an independent authority. This ensures that an investor's rights to fair administrative action are realised. ${ }^{95}$

Fourth, and more interestingly, the 2016 SADC FIP notes that where a payment is significantly burdensome on a host state, such a state may pay the amount due yearly over a 3-year period. ${ }^{96}$ Alternatively, the investor and the host state may agree on a suitable period and interest rate. ${ }^{97}$ The option to stagger the payment for expropriation or nationalisation is crucial in the developing country context, where resources may not always be available to immediately provide for compensation.

Lastly, the 2016 SADC FIP addresses the issue of indirect expropriation. It provides that where the host state undertakes a measure of general application "that is designed and applied to protect and enhance legitimate public welfare objectives, such as public health, safety and the environment, it shall not constitute indirect expropriation". This is important because it reinforces the crucial right to regulate, which will be discussed in a later section. Furthermore, it protects the host state from frivolous and litigious suits related to the indirect expropriation of investments owing to a domestic

\footnotetext{
92 Commentary on art 6 of the SADC Model BIT.

93 Article 5(3) of the 2016 SADC FIP.

94 Article 5(4) of the 2016 SADC FIP.

95 This is an important right in some jurisdictions. For instance, South Africa enshrines this right in s 33 of the Constitution, while Zimbabwe provides for a similar right in s 68 of its Constitution. Interestingly the South African Protection of Investment Act has a right to fair administrative treatment in place of the fair and equitable treatment clause.

96 Article 5(4) of the 2016 SADC FIP.

97 Article 5(4) of the 2016 SADC FIP.
} 
measure. An interesting case in this regard is the Foresti case in South Africa, where the state was sued for a claim under the Italian and Luxembourg BITs. ${ }^{98}$ The specific challenge by the investors was that South Africa's application of its BEE policy in terms of the Mineral and Petroleum Resources Development Act resulted in the indirect expropriation of the claimant's shares. While the case was later withdrawn by the claimant after a resolution was put in place by the state, it highlighted the ability of investors to challenge key social and economic development measures under traditional investment clauses. ${ }^{99}$

\subsubsection{Fair and equitable treatment}

The fair and equitable treatment standard is a broad standard of protection which has attracted a fair amount of controversy. ${ }^{100}$ It requires that a state must provide the investments or return on investments of an investor's fair and equitable treatment. ${ }^{101}$ This in itself is not clear and generally leads to broad interpretations. Attempts to narrow the standard have been done in some cases by linking it to the international minimum standard, the full protection and security standard or customary international law. ${ }^{102}$ These attempts have not been successful, however, as arbitral tribunals continue to interpret the provision broadly. ${ }^{103}$

The 2006 SADC FIP provided for an "autonomous" fair and equitable treatment standard. It briefly stated that "Investments and Investors shall enjoy fair and equitable treatment in the territory of any State Party". ${ }^{104}$ As is evident from this provision, there was no clarity on the meaning of fair and

98 Piero Foresti, Laura de Carli $v$ Republic of South Africa ICSID Case No ARB $(\mathrm{AF}) / 07 / 1$.

$99 \quad$ See generally Lim Alternative Visions 306.

100 See Solanes and Jouralev Revisiting Privatisation 34.

101 Article 7 of the Ghanaian Investment Promotion Act (GN 131 of 2009). According to Bonnitcha $J$, the fair and equitable standard seems to have emerged from art 11(2) of the failed Havana Charter of the International Trade Organisation (ITO) (1948), which provided for "just and equitable treatment", after which the obligation to provide fair and equitable treatment surfaced in FCN Treaties. See Bonnitcha Substantive Protection under Investment Treaties 143.

102 Tudor Fair and Equitable Treatment Standard 66. UNCTAD notes that the linking of the fair and equitable treatment standard and the international minimum standard by a growing number of studies is without merit. This judgment is reinforced by the OECD, which states that fair and equitable treatment does not automatically include the international minimum standard. See UNCTAD 2012 http://unctad.org/en/Docs/unctaddiaeia2011d5_en.pdf 23.

103 Porterfield $2013 \mathrm{https}: / / w w w . i i s d . o r g / i t n / 2013 / 03 / 22 / a-d i s t i n c t i o n-w i t h o u t-a-$ difference-the-interpretation-of-fair-and-equitable-treatment-under-customaryinternational-law-by-investment-tribunals/. Article 6(1) of Annex 1 of the SADC FIP. 
equitable treatment. This view is reinforced by the Waste Management $v$ United Mexican States ${ }^{105}$ case, where it was noted that "the standard is to some extent a flexible one which must be adapted to the circumstances of a particular case". ${ }^{106}$ This then brought to the fore the need to revisit the usage of this standard in the SADC FIP.

A number of options were available for resolving the challenges brought about by the fair and equitable treatment standard. These included: (1) linking the fair and equitable standard to customary international or the international minimum standard, (2) providing an exhaustive list of obligations related to fair and equitable treatment, (3) completely eliminating the standard of fair and equitable treatment from the treaty, and (4) providing an alternative formulation of the fair and equitable treatment such as fair administrative treatment. ${ }^{107}$

To analyse: the first option is rendered impractical because of the refusal of arbitral tribunals to recognise efforts to limit the interpretation of the standard in cases such as the Railroad Development Corp v Guatemala. ${ }^{108}$ Similarly, the third option is hamstrung by the frequent desire of states to include the fair and equitable treatment standard despite its general weaknesses. ${ }^{109}$ The fourth option is more practical as it provides a narrower scope. This is the option adopted by South Africa in its Protection of Investment Act. The Drafting Committee of the SADC Model BIT was suitably impressed with this option, as it narrows the scope of the current fair and equitable treatment standard, thereby eliminating the possibility of an expansive interpretation. The challenge with this, however, is the shift in the drafting language from investor rights to governance standards, which drastically lessens the protection that should be granted to an investor according to customary international law. In this regard, the alternative formulation of the fair and equitable treatment standard becomes too narrow. Furthermore, it

105 Waste Management $v$ United Mexican States ICSID Case No ARB(AF)/00/3.

106 Waste Management $v$ United Mexican States ICSID Case No ARB(AF)/00/3 para 99. This is supported by the averments of Professor Muchlinski on the matter. He states that: "[t]he concept of fair and equitable treatment is not precisely defined. It offers a point of departure in formulating an argument that the foreign investor has not been well treated by reason of discriminatory or other unfair measures being taken against its interests. It is, therefore, a concept that depends on the interpretation of specific facts for its content. At most, it can be said that the concept connotes the principle of non-discrimination and proportionality in the treatment of foreign investors". See Muchlinski Multinational Enterprises and the Law 625.

107 See Leite 2016 Am U Int'l L Rev 397 for other options.

108 Railroad Development Corp v Guatemala ICSID Case No ARB/07/23.

109 This is explained by states' wanting to use alternative formulations of the rule so as to limit it. 
can be noted that protection is already given in domestic law as part of substantive and procedural fairness. ${ }^{110}$ This leaves the second option as the only practical option.

The 2016 SADC FIP, however, adopts the more radical third approach. The fair and equitable treatment standard is not included in this document. The reasoning behind this can be found in the Preamble of the 2016 SADC FIP, where the State Parties noted that some of the provisions in the 2006 SADC FIP fail to adequately balance investor protection and the host state's need for development policy space. The result of this, they noted, was that in their previous form some of the provisions could have unintended consequences for SADC Member States. ${ }^{111}$ Despite these novel assertions, it is contended that a less restrictive option could have been adopted. It is important that the SADC FIP should clearly articulate the need for a transparent and predictable regulatory environment which protects investors from arbitrary or abusive conduct by a host state through a qualified fair and equitable treatment clause. ${ }^{112}$ Such an approach balances investment protection and the competing policy objectives of the host state.

\subsubsection{The repatriation of funds and transfer of profits}

One of the cornerstone principles in foreign investment law is that investments and their profits should be able to be repatriated. ${ }^{113}$ Generally, investors are not willing to make investments in a foreign country where they will be unable to repatriate the profits from the operations or the funds for the partial or complete sale of the original investment. ${ }^{114}$ The same sentiment is shared by the government of the country of the investor, which also stands to benefit economically from such repatriation. ${ }^{115}$ The result is that most investment treaties contain a clause on how capital and funds will be repatriated.

In the light of the above, the 2006 SADC FIP provided for the free movement of capital, subject to restrictions in certain instances. ${ }^{116}$ It stated that "State Parties shall encourage the free movement of capital". ${ }^{117}$ This was qualified,

\footnotetext{
110 See for example s 33 of the South African Constitution and s 68 of the Zimbabwean Constitution.

111 Preamble of the 2016 SADC FIP.

112 PMG 2015 http://pmg-assets.s3-website-eu-west-1.amazonaws.com/150916 Summary.pdf.

113 Viterbo International Economic Law and Monetary Issues 244.

114 Woodbridge Next World War 120.

115 Muchlinksi, Ortino and Schreuer Oxford Handbook 331.

116 Article 15 of Annex 1 of the 2006 SADC FIP.

117 Article 15(1) of Annex 1 of the 2006 SADC FIP.
} 
however, by Article 15(2) of Annex 1 of the 2006 SADC FIP, which provided that:

Notwithstanding the provisions of paragraph 1, State Parties may regulate capital movements subject to their domestic laws and regulations, when necessitated by economic constraints. ${ }^{118}$

This qualification was important for two reasons. First, it allowed state parties the leeway to use domestic laws and policy to counter tough macroeconomic challenges by restricting the transfer of funds which could facilitate sustainable economic development. Secondly, it raised a question about what would qualify as a genuine economic constraint. This made the application of the provision very subjective and prone to abuse.

The 2016 SADC FIP maintained the core formulation of the 2006 SADC FIP in relation to the repatriation of funds. The most significant change in relation to this provision was the inclusion of an indicative list of what could qualify as economic constraints. This was key because it partially limits the possibility of abuse by Member States.

\subsection{The rights and obligations of investors and State Parties}

\subsubsection{The right to regulate}

It is trite that a state has the sovereign right to regulate within its borders. This is equally true in the context of international investment law. As noted in $A D C \vee$ Hungary, a state has an inherent right to regulate, subject to limitations. ${ }^{119}$ On the matter of this right Salacuse expressed the opinion that:

\footnotetext{
With respect to foreign investment, states have the complete legislative jurisdiction to determine to what extent foreign nationals and companies may undertake investments, which sectors and industries they may or may not enter, and whether or not they must fulfil additional conditions in order to undertake and operate an investment within state territory. ${ }^{120}$
}

As is evidenced above, the right to regulate gives host states autonomy to control how investments are regulated within their territories. As a result, this is a highly cherished right in international investment law, one which states will not give up lightly, as it has important implications for national

\footnotetext{
118 Article 15(2) of Annex 1 of the 2006 SADC FIP.

$119 A D C$ v Hungary ICSID Case No ARB/03/16 of 2 October 2006.

120 Salacuse Law of Investment Treaties 191; Sornarajah International Law on Foreign Investment 311.
} 
policy space and regulatory flexibility for development, ${ }^{121}$ and has public welfare implications. ${ }^{122}$

Consistent with the need for states to control investments within their territories, the 2006 SADC FIP provided for the right to regulate. ${ }^{123}$ This right to regulate could typically be invoked in the interest of the public so as to ensure that foreign investments accord with health, safety or environmental requirements. ${ }^{124}$ However, the difficulty was that public interest as a regulatory interest was not adequately captured. It is not enough to refer to the right to regulate in the public interest, as is often done, as this does not narrow the possible meanings of public interest. ${ }^{125}$

There have been various ways of trying to give meaning to the right to regulate in the public interest. The Preamble of the Protection of Investment Act in South Africa, for instance, provides that the government has a right to regulate in the interests of the public in accordance with the Constitution. While this does little to bring clarity to the meaning and scope of the right to regulate in the public interest, it does provide context as to how the right should be exercised.

Another way is to provide an illustrative list of matters generally deemed as forming part of the right to regulate in the public interest. A good starting point is to observe the matters referred to by Nikièma as forming part of public interest. He notes that "public interest is a broad concept that includes public order, public health, national security, human rights, public morals and environmental protection". ${ }^{126}$ However, Titi limits the scope of public interest in the context of the right to regulate. He believes that "the right to regulate in the public interest is understood to encompass regulation with a basis other than a state of necessity, national security or the public order". ${ }^{127}$ Titi's interpretation is consistent with provisions in recent texts on the right to regulate. For example, the Norwegian 2015 Model BIT takes into account only matters related to safety, human rights, labour rights, resource

\footnotetext{
121 See generally Alvarez Public International Law Regime 223.

122 It is important to regulate foreign investment in terms of public welfare, because foreign investors might, for example, pollute the air, which would affect the general public of the host state.

123 See art 14 of Annex 1 of the 2006 SADC FIP.

124 Article 14 of Annex 1 of the 2006 SADC FIP.

125 Titi avers that "[a]t a national level the public interest may thus be explained as a nation's general welfare and well-being". See Titi Right to Regulate in International Investment Law 100.

126 Nikièma 2012 http://www.iisd.org/pdf/2012/best_practice_indirect_expropriation.pdf 3.

127 Titi Right to Regulate in International Investment Law 100-101.
} 
management and environmental concerns when dealing with the right to regulate. ${ }^{128}$

It is also important to note that the exercise of the right to regulate may result in direct or indirect expropriation. For instance, the Tribunal in Desarrollo de Santa Elena S.A. $v$ The Republic of Costa Rica ${ }^{129}$ had to make a determination on indirect expropriation and state regulation for the public purpose of protecting the environment. In reaching a decision, the tribunal noted that despite the fact that the expropriation had been done for the legitimate purpose of regulating to protect the environment, this did not absolve the government from paying compensation. ${ }^{130}$ In the words of the Tribunal:

$[T]$ he purpose of protecting the environment for which the Property was taken does not alter the legal character of the taking for which adequate compensation must be paid. The international source of the obligation to protect the environment makes no difference. ${ }^{131}$

Therefore, while a state has a right to regulate, the exercise of this right comes with the concomitant responsibility to compensate an affected investor, where such a measure leads to expropriation. ${ }^{132}$ It is therefore critical that the right to regulate be read with other provisions such as national treatment or expropriation and compensation.

The 2016 SADC FIP expressly provides for the right to regulate in Article 14. It states that a host state has a "right to regulate in the public interest and to adopt, maintain or enforce any measure that it considers appropriate to ensure that investment activity is undertaken in a manner that is sensitive to health, safety or environmental concerns". The proposal by South Africa was, however, that this provision be redefined. ${ }^{133}$ Its view was that the current text had to be replaced by a clearer and more detailed provision. The recommended provision reads as follows:

\footnotetext{
128 See art 12 of the Norway Model Bilateral Investment Treaty (2015).

129 Desarrollo de Santa Elena S.A. $v$ The Republic of Costa Rica ICSID Case No. ARB/96/1 of 17 February 2000.

130 Desarrollo de Santa Elena S.A. $v$ The Republic of Costa Rica ICSID Case No. ARB/96/1 of 17 February 2000 para 71 . The Tribunal noted that the government of Costa Rica had a right in international law to expropriate property against the payment of prompt, adequate and effective compensation.

131 Desarrollo de Santa Elena S.A. v The Republic of Costa Rica ICSID Case No. ARB/96/1 of 17 February 2000 para 71.

132 See generally Adeleke 2015 http://www.saiia.org.za/policy-insights/benchmarkingsouth-africas-foreign-direct-investment-policy 3.

133 PMG 2016 http://pmg.org.za/files/150922summary.pdf.
} 
In accordance with customary international law and general principles of international law, the Host State has the right to take regulatory or other measures to ensure that development in its territory is consistent with the goals and principles of sustainable development, and with other legitimate social and economic policy objectives. ${ }^{134}$

This provision crystallises the right to regulate in the public interest of the state in international law. This provision by virtue of its drafting also eliminates any ambiguity related to the powers of the state to take regulatory measures or otherwise to promote the welfare and interests of its people. This in turn reduces the possibility for litigation. As a result, the 2016 SADC FIP integrates this suggestion verbatim in Article 12(1). Two further subsections were added, however. Article 12(2) reinforces the contents of Article 12(1) by noting that an exercise of the right to regulate should be understood as forming part of the balance of rights and obligations of investors and host states. Article 12(3) notes that non-discriminatory measures taken in order to comply with international obligations under other treaties do not constitute a breach of the 2016 SADC FIP.

\subsubsection{Transparency}

Notwithstanding its declining use, ${ }^{135}$ the transparency clause remains a fundamental feature of the new generations of BITs. ${ }^{136}$ It generally provides that the host state must be transparent in its laws, regulations, administrative practices and procedures. ${ }^{137}$ To meet this requirement the government must publish its policies in places such as the Government Gazette so as to inform concerned parties of their rights and obligations. ${ }^{138}$ The rationale behind these clauses is that "[t]ransparency is a crucial determinant of the political and economic risk foreign investors face when making a foreign investment decision". ${ }^{139}$ The difficulty with this approach is that it focuses on the state and its institutions but fails to demand the

\footnotetext{
134 PMG 2016 http://pmg.org.za/files/150922summary.pdf.

135 Houde "Novel Features in Recent OECD Bilateral Investment Treaties" 153.

136 OECD Investment Policy Reviews: Russian Federation 2006 73; Van den Berg International Commercial Arbitration 54.

137 The United States of America (USA), for example, has strong transparency measures which require transparency in host-state measures. See United States of America Model Bilateral Investment Treaty (2015) (USA 2012 Model BIT). After the 2004 amendment, NAFTA's art 11 also contains a broad clause on transparency. See art 11 of NAFTA; Vandevelde US International Investment Agreements 424.

138 Nde Fru International Law on Foreign Investments 69.

139 Rosendorff and Shin 2012 https://wp.nyu.edu/faculty-rosendorff/wpcontent/uploads/sites/1510/2015/03/RosendorffShinAPSA2012.pdf 6.
} 
same amount of transparency from all actors, including foreign investors and their home states. ${ }^{140}$

The 2006 SADC FIP also contained a moderate version of this novel clause. Article 8 provides that in order to create confidence, trust and predictability, the state parties have to adopt transparent laws and policies related to investment. ${ }^{141}$ This provision, therefore, necessitated that state parties be transparent in their laws and policies related to investment. This was important because investors generally want to peruse the laws and policies of a country before investing.

The 2016 SADC FIP maintains the transparency provision in the 2006 SADC FIP as subsection 1 of Article 7. In subsection 2 of the Article, however, it obliges Member States who introduce regulations which affect the contents of the SADC FIP to notify the SADC Secretariat for information 3 months before introducing such a regulation. This provision was previously contained in Article 15(3) of Annex 1 of the 2006 SADC FIP. Therefore, there are no significant changes to the transparency clause.

\subsubsection{Sustainable development: the optimal use of natural resources and environmental measures}

The optimal use of natural resources is a rarely used clause in the treaty system, which accords with the objectives of sustainable development and the preservation of the environment. ${ }^{142} \mathrm{~A}$ typical clause provides that the host state must guarantee that natural resources within its borders are used in a manner that is environmentally friendly and sustainable. Some treaties would generally prefer to canvass these ideas in separate clauses on sustainable development and the environment.

The 2006 SADC FIP contained an independent clause on the optimal use of natural resources. ${ }^{143}$ It provided that "State Parties shall promote the use of their natural resources in a sustainable and environmentally friendly manner". ${ }^{144}$ The 2016 SADC FIP maintains this provision. In the developing country context, this is a key provision in ensuring that resources are

\footnotetext{
$140 \quad$ Muchlinski, Ortino and Schreuer Oxford Handbook 627.

141 Article 8 of Annex 1 if the 2006 SADC FIP.

142 Albath Trade and Energy 72; Dupy, Francioni and Petersman Human Rights in International Investment Law 484; Gazzini Interpretation of International Investment Treaties 161.

143 See art 12 of Annex 1 of the 2006 SADC FIP.

144 Article 12 of Annex 1 of the 2006 SADC FIP.
} 
optimally utilised. Further revisions should be made to this provision, however, so as to adequately link it to sustainable development.

\subsubsection{Key personnel}

Key personal provisions in a treaty regulate how a foreign company can fill important vacancies within its structure. ${ }^{145}$ This provision is vital in determining how a foreign enterprise will fill key managerial positions as part of its strategic plans. ${ }^{146}$ This is because these companies are always looking to bring expatriates in to take up positions requiring special skills. ${ }^{147}$ This provision is expressed differently in investment treaties. Some of its forms include entry and sojourn, key personnel, permits, and the sourcing of requisite skills.

Both the 2006 SADC FIP and the 2016 SADC FIP express their clauses on foreign personnel as the "sourcing of requite skills". ${ }^{148}$ The provision states that:

State Parties shall, subject to their national laws and regulations, permit investors to engage key personal and other necessary human resources of their choice, regardless of their nationality, under the following circumstances:

(a) where the skills do not exist in the Host State and the Region,

(b) where State Parties are satisfied that the sourcing of such skills will be in compliance with regional policies; and where such sourcing would enhance the development of local capacity through skills transfer. ${ }^{149}$

While this provision is partially protectionist, it supports the domestic policies of the Member States. Most countries now seek to ensure that investments benefit their citizens through employment, and as a result, they want to ensure that investors bring in only specialised employees who will transfer their skills to locals. ${ }^{150}$

145 Caliskan Development of International Investment Law 144.

146 Collins Introduction to International Investment Law 152.

147 Houde "Novel Features in Recent OECD Bilateral Investment Treaties" 155.

148 See art 11 of Annex 1 of the 2006 SADC FIP.

149 Article 11 of Annex 1 of the 2006 SADC FIP.

150 Xenophobic tendencies in countries such as South Africa, Botswana and Namibia are also good reasons for this provision. If investors are not restricted in bringing in foreign employees, locals may start to feel as though the expatriates are taking over their jobs. 


\subsubsection{Corporate responsibility}

The clause on CSR has recently surfaced in international investment agreements. ${ }^{151}$ In this regard some Model BITs have made specific reference to CSR. ${ }^{152}$ These include the 2007 Norway Draft Model BIT, the 2012 Canadian Model BIT, and more recently the 2015 Indian Model BIT and the 2015 Norway Model BIT. To focus on the 2015 Norway model BIT, this document emphasises the importance of CSR in its preamble. ${ }^{153}$ Article 31 provides that:

\section{The Parties agree to encourage investors to conduct their investment activities in compliance with the OECD Guidelines for Multinational Enterprises, the UN Guiding Principles on Business and Human Rights and to participate in the United Nations Global Compact. ${ }^{154}$}

The CSR clause, therefore, is important in promoting the social, ethical, human rights and environmental obligations of investors beyond their legal and economic duties. ${ }^{155}$ This moves away from the current practice of asking for voluntary compliance with CSR standards and imposes a duty of discharging CSR. ${ }^{156}$ As argued by Pillay, a CSR clause is vital, particularly for developing countries, as it promotes their "power to regulate to achieve sustainable development". ${ }^{157}$

Article 10 of Annex 1 of the 2006 SADC FIP provided for corporate responsibility. It states that "[f]oreign investors shall abide by the laws, regulations, administrative guidelines and policies of the Host State". ${ }^{158}$ The language of this provision is retained in the 2016 SADC FIP with reference to investor responsibility. The challenge with this drafting is that it focuses on compliance with domestic laws and procedures but does not require the investor or the investment to comply with international standards or to participate in international bodies, as is required by the CSR clause in the 2015 Norway model BIT, for example. There is therefore a need to clarify the corporate responsibility clause in the SADC FIP so as to shift its emphasis from the current specific compliance with law and policy to a broader and more general compliance.

\footnotetext{
151 Bjorklund Yearbook on International Investment Law and Policy 433.

152 Sauvant Yearbook on International Investment Law and Policy 600.

153 Preamble of the 2015 Norway Model BIT.

154 Article 31 of the 2015 Norway Model BIT.

155 See Mallin Corporate Social Responsibility 129.

156 Titi Right to Regulate in International Investment Law 110.

157 Pillay Changing Nature of Corporate Social Responsibility 197.

158 Article 10 of Annex 1 of the 2006 SADC FIP.
} 


\subsection{General provisions}

\subsubsection{Exceptions}

A small but growing number of international investment agreements, particularly free trade agreements (FTAs), contain exception clauses. ${ }^{159}$ In most instances, a treaty will contain an exception clause related to either Article XX of the GATT or Article XIV of the GATS. However, in some cases, a hybrid exception clause is provided. ${ }^{160}$ Beyond the differences in formulation, the purpose of these clauses is to increase regulatory flexibility, balance the interests of investors and host states, and enhance legal certainty where disputes arise.

Exceptions in a treaty can be either general or special. General exceptions apply to all the obligations in a treaty, while special exceptions apply to certain obligations only. On the one hand, special exceptions usually focus on national treatment and MFN treatment, while on the other hand, general exceptions cover issues ${ }^{161}$ such as human rights, public order, public employment, labour standards, the environment, taxation and security. ${ }^{162}$ Recently the trend in international investment agreements has been to include special exceptions. The SADC FIP does not deviate from this norm.

The 2006 SADC FIP allowed for special exceptions to the application of the fair and equitable treatment standard and MFN treatment. The implications of these exceptions were that the state could grant differential treatment to investors. For instance, pursuant to Article 7(1) of the 2006 SADC FIP, a state party could "grant preferential treatment to qualifying investments and investors in order to achieve national development objectives". ${ }^{163}$

159 See Newcombe and Paradell Law and Practice of Investment Treaties 500; Desierto Public Policy in International Economic Law 327.

160 Sabanogullari 2015 https://www.iisd.org/itn/2015/05/21/the-merits-and-limitationsof-general-exception-clauses-in-contemporary-investment-treaty-practice/.

161 Vandevelde classifies the issues treated in general exceptions into four main areas, namely: "the security of the state against external threats or internal disorder, the preservation and protection of life (including the physical environment that makes life possible), the regulation of the economy, and the preservation of diverse cultures". See Vandevelde 2013 LCLR 450.

162 It is argued that in new generation BITs, exceptions related to public order and security have fallen away in favour of security exceptions related to the regulation of financial services, the preservation of culture and industries and the protection of health, safety and the environment. See Nhamo and Chekwoti Land Grabs in a Green Economy 49.

Article 7(1) of Annex 1 of 2006 the SADC FIP. 
The 2016 SADC FIP does not contain an exceptions clause. Neither does it contain an MFN clause or the fair and equitable treatment standard. Rather, it provides a national treatment clause with built-in exceptions. It provides that host states may grant "preferential treatment to domestic investments and investors in order to achieve national development objectives". ${ }^{164}$ These exceptions, as discussed earlier, are crucial to ensuring that the right to regulate is not unnecessarily impeded.

\subsection{Dispute resolution}

With the constant evolution of international investment law, which brings about uncertainty, dispute resolution has become a fundamental area in treaties. Dispute settlement mechanisms permit an investor to initiate proceedings against a host-state in domestic and international forums. ${ }^{165}$ Internationally, the fora available to the investor include the International Centre for the Settlement of Disputes (ICSID) and the United Nations Commission on International Trade Law (UNCITRAL). Each of these institutions has its own rules and arbitral tribunals. ${ }^{166}$

Dispute resolution clauses, in particular investor-state arbitration provisions, have been at the centre of much controversy, as they have exposed many developing states to heavy penalties for breaching investment agreements. ${ }^{167}$ For example, in 2012 an investor from the USA was awarded almost US\$ 1.9 billion for a claim against Ecuador. ${ }^{168}$ Zimbabwe, for one, has lost arbitral proceedings at the ICSID and SADC Tribunals. ${ }^{169}$ Such losses have led to a growing movement for the provision of nonbinding investor-state dispute settlement mechanisms. This has been embraced mostly in investment chapters in FTAs, with the exception of some BITs such as those of Australia. ${ }^{170}$ While BITs focus on both investorstate arbitration and state-state arbitration, FTAs and their investment chapters focus on investor-state arbitration, which is viewed as being more

\footnotetext{
164 Article 6(3) of the 2017 SADC FIP.

165 Schill International Investment Law 13.

166 See the International Centre for Settlement of Disputes Convention (1965) and the United Nations Convention on the Recognition and Enforcement of Foreign Arbitral Tribunal Awards (1958) (New York Convention).

167 Van Duzer, Simons and Mayeda Integrating Sustainable Development 411.

168 Ocidental Petroleum v Ecuador ICSID Case No ARB06/11 of 5 October 2012.

169 See, for example, Mike Campbell (Pvt) Ltd v Republic of Zimbabwe 2008 SADCT 2 of 28 November 2008; Bernadus Henricus Funnekotter $v$ Republic of Zimbabwe ICSID Case No ARB/05/06; and Bernhard von Pezold $v$ Republic of Zimbabwe ICSID Case No ARB/1/15.

170 Bjorklund and Reinisch International Investment Law 218.
} 
pertinent in such agreements. ${ }^{171}$ This is problematic as it closes the avenue to state-state dispute resolution where the state is an interested party.

For the above reasons, the 2006 SADC FIP only provided for investor-state arbitration. Article 28 on the settlement of disputes provided that if a dispute was not satisfactorily resolved after 6 months of a notice of claim and all local remedies had been exhausted, a party could submit the dispute for international arbitration. ${ }^{172}$ The fora available to the investor in terms of this provision were the SADC Tribunal, the ICSID, and an international arbitrator or ad hoc arbitral tribunal established pursuant to a special agreement or constituted in terms of the New York Convention rules. ${ }^{173}$ In addition to this, investors were also granted in Article 27 access to domestic courts, judicial and administrative tribunals, or other competent authorities which could redress the grievances of the investor.

The 2016 SADC FIP maintains access to domestic courts and tribunals for investors in Article 25. However, in Article 26 it makes a hard exit from investor-state arbitration. It provides that any dispute between state parties will be resolved in the manner provided for under the Protocol of the Tribunal. Effectively, this means that the 2016 SADC FIP deals with statestate arbitration only. This is in line with the proposal by South Africa that Article 28 of the 2006 SADC FIP be removed as a result of concerns with the settlement of investor-state disputes by international tribunals. These concerns included inter alia the "perceived lack of transparency and legitimacy of the international arbitration process, conflicting arbitral jurisprudence, the independence of arbitrators and the prohibitive legal costs associated with international commercial arbitration and excessive damages". ${ }^{174}$

Second, the inclusion of the toothless SADC Tribunal as an arbitral body is problematic. This is because the legitimacy of this body is questionable. The SADC Tribunal became defunct after the case of Mike Campbell (Pvt) Ltd $v$ Republic of Zimbabwe, ${ }^{175}$ where Zimbabwe refused to abide by the decision of the tribunal after being found in breach of its obligations under the SADC Treaty. More specifically, the state had unlawfully expropriated private property without compensation. Zimbabwe cited the illegitimacy of the

\footnotetext{
171 See Pryles Dispute Resolution in Asia 107; Hamilton et al Latin American Investment Protection 589.

172 Article 28(1) of Annex 1 of the 2006 SADC FIP.

173 Article 28(2) of Annex 1 of the 2006 SADC FIP.

174 PMG 2016 http://pmg.org.za/files/150922summary.pdf.

175 Mike Campbell (Pvt) Ltd $v$ Republic of Zimbabwe 2008 SADCT 2 of 28 November 2008.
} 
Tribunal as one of its grounds for non-compliance ${ }^{176}$ and exerted political pressure which led to the suspension of the SADC Tribunal. ${ }^{177}$ Following this process, the SADC leaders, through the SADC Summit, reviewed the powers of the tribunal, opting for granting it a more limited scope. One may question the efficacy of attempting to rely on an arbitral tribunal that has been branded as illegitimate. It would perhaps be better to err on the side of caution and focus on the UNCITRAL and ICSID tribunals, which are generally viewed as legitimate and competent bodies.

\section{Conclusion}

The changes made in the 2016 SADC FIP are commendable to a great degree. In its previous form, it provided antiquated provisions which are typical of first-generation BITs. These provisions failed to balance the rights and obligations of investors and state parties. Furthermore, the provisions exposed host states to onerous investment arbitration claims. The 2016 SADC FIP addresses most of these concerns by drawing from some South African recommendations, the SADC Model BIT, and some international best practices.

The 2016 SADC FIP eliminates problematic clauses such as the fair and equitable treatment clause, which is a "cure it all" remedy for investors, and the MFN clause, which leads to treaty shopping by investors. The 2016 SADC FIP also clarified other provisions such as those on the repatriation of funds and expropriation. There is now greater certainty with regards to these provisions. For example, a proper procedure is laid out for calculating the compensation due to an investor. More importantly, the 2016 SADC FIP introduced a qualified national treatment clause which allows host states to afford preferential treatment to their nationals in line with their developmental objectives. This is vital in the developing country context and it also accords with the constitutional mandates to redress injustices of the past in Member States such as Zimbabwe and South Africa. The 2016 SADC FIP also restricted the scope of an investment by shifting from an open-list asset-based definition to an enterprise-based definition. This ensures that only assets related to the enterprise are covered by the agreement.

176 The North Gauteng High Court in South Africa registered the ruling in South Africa and permitted the farmers to attach Zimbabwe's property in South Africa. The process has since been delayed by the intervention of the South African government. See Ndlovhu 2011 LDD 69.

177 Geldenhuys 2012 https://tradelawchambers.com/raxo-what-s-on/116-a-new-sadctribunal. 
However, seven issues still need to be addressed, some of these arising from the changes to the 2006 SADC FIP. These relate to: (1) the definition of investors, (2) the omission of the fair and equitable treatment standard, (3) the scope of the transparency clause, (4) the alignment of the optimal use of natural resources clause with sustainable development, (5) the shift away from investor-state arbitration, (6) the expansion of the investor liability clause, and (7) the inclusion of a physical security clause.

\section{The definition of investors}

The definition of an investor was narrowed from including any person who has been admitted to make an investment so that it now refers only to "a natural or a juridical person of another State Party, in accordance with the laws and regulations of the State Party in which the investment is made". ${ }^{178}$ This limits the protection offered to SADC investors only. This is problematic, given the fact that there are very few intra-SADC investments. Protection is therefore no longer extended to the SADC's main investors.

Furthermore, the definition of investors in the 2016 SADC FIP still does not address the issue of investors with dual nationalities or companies that are effectively managed in other jurisdictions. The 2016 SADC FIP could perhaps emulate the SADC Model BIT, which resolves these issues. On the matter of dual citizenship, the SADC Model BIT proposes that a natural person would be given protection under a treaty only if he/she was predominantly resident in the host state. ${ }^{179}$ As regards the issue of effective management, the SADC Model BIT proposes that a juridical person should be legally incorporated in the host state, effectively owned or controlled by a natural person in the host state, and should have substantial business in the host state. ${ }^{180}$ As regards the scope of the definition, it would be useful to revert to the definition contained in the 2006 SADC FIP on the condition that disputes between a member state and an investor will be in accordance with the law of such a member.

Article 2 of the 2016 SADC FIP.

Article 2 of the SADC Model BIT.

Despite these inherent weaknesses, the definition of an investor is meritable as it does not limit investors to those in a particular geographic region, such as SADC members, as is done in the CCIA. See Claypoole 2013 http://www.lexology.com/library/detail.aspx?g=e420a271-0395-4751-ada5dcb985104307. 


\title{
The omission of the fair and equitable treatment standard
}

In terms of the fair and equitable treatment standard, a more viable approach would have been to provide an exhaustive list qualifying the fair and equitable treatment standard so as to limit its application. A preferred formulation is one stipulated in the Canada Comprehensive Economic Trade Agreement (CETA), which provides that:

\begin{abstract}
A Party breaches the obligation of fair and equitable treatment referenced in paragraph 1 where a measure or series of measures constitutes: (a) Denial of justice in criminal, civil or administrative proceedings; (b) Fundamental breach of due process, including a fundamental breach of transparency, in judicial and administrative proceedings. (c) Manifest arbitrariness; (d) Targeted discrimination on manifestly wrongful grounds, such as gender, race or religious belief; (e) Abusive treatment of investors, such as coercion, duress and harassment; or ( $f$ ) A breach of any further elements of the fair and equitable treatment obligation adopted by the Parties in accordance with paragraph 3 of this Article. ${ }^{181}$
\end{abstract}

The closed nature of this list eliminates the possibility of a broad interpretation by arbitral tribunals. It also curbs the need for non-compliance by some Member States in an effort to avoid the broad provisions of the standard. ${ }^{182}$ Furthermore, it could also be stipulated that the exercise of the right to regulate in the public interest does not constitute a breach of the fair and equitable treatment standard. This would further mitigate the risks host states face from broad interpretations of the standard. It would also facilitate transformational policies which could be deemed as violating the fair and equitable treatment standard.

The scope of the transparency clause

With regards to the transparency provision, the recommendation is that in the interest of progressiveness the provision on transparency in the 2016 SADC FIP should be extended to investors and their home states. The SADC Model BIT already extends the obligation of transparency to investors and host states in terms of contracts and payments. ${ }^{183}$

\footnotetext{
181 Article 9 of the EU-Canada Comprehensive Economic Trade Agreement (2016) (CETA).

182 South Africa, for one, has deliberately excluded the fair and equitable treatment clause in its domestic regulation. 
The alignment of the optimal use of natural resources clause to sustainable development

In terms of the optimal use of natural resources clause, it is recommended that this provision be aligned to sustainable development. This is due to the interconnectedness of sustainable development, environmental measures ${ }^{184}$ and the use of natural resources. It is recommended that these clauses be consolidated in one clause on sustainable development, which is an important thrust in modern international investment law. The provision would read that: 185

(a) State Parties should promote the use of their natural resources in a manner that promotes sustainable development.

(b) More broadly, Member States should take measures to protect the environment, human rights, safety, health and labour rights, pursuant to their right to regulate, the measures of which cannot be relaxed to promote foreign investment.

This provision would clearly articulate the wish of the Member States to use BITs to promote investment, but such development ought to be sustainable.

The shift away from investor-state arbitration

While the shift away from investor-state arbitration eases the concerns of host states with regard to unreasonable arbitral awards, it raises new concerns about the adequacy of the recourse mechanism available to SADC investors. ${ }^{186}$ The SADC Tribunal, which is now the main mechanism for resolving investment disputes in the SADC, has in the past failed to enforce its judgements. Furthermore, while investors retain their right to access domestic courts, it is worth noting that domestic courts are subject

184 Article 13 of Annex of the SADC FIP on environmental measures provides that: "State Parties recognise that it is inappropriate to encourage investment by relaxing domestic health, safety or environmental measures and agree not to waive or derogate from international treaties they have ratified, or offer to waive or otherwise derogate from such measures as an encouragement for the establishment, acquisition, expansion or retention in their territories of an investment".

185 This provision combines and clarifies arts 12 and 13 of the SADC FIP.

186 It also raises issues about a lack of consistency in the application of the law. For example, would a dispute between Zimbabwe and South Africa be dealt with in terms of the Agreement between the Government of the Republic of South Africa and the Government of the Republic of Zimbabwe for the Promotion and Reciprocal Protection of Investments (2009) or in terms of the dispute resolution clause in the SADC FIP? 
to the influence of the host state and can therefore lack impartiality. As a result, the mechanisms for resolving disputes are currently inadequate. The suggestion is that investor-state arbitration be made an option of last resort after all domestic avenues have been exhausted.

Expansion of the investor liability clause (CSR)

Another provision that needs revision is the investor liability clause. While this provision is noble in that it places an obligation on investors to comply with domestic rules and regulations, it is too narrow. The suggestion in this regard is that the clause should be extended to include requiring investors to act in accordance with the UN Guiding Principles on Business and Human Rights and to participate in the United Nations Global Compact.

The inclusion of a physical security clause

One final issue that was not addressed in the amendment is the introduction of a full protection and security clause framed as "physical security". Both the 2016 SADC FIP and the 2006 SADC FIP do not include this provision, which is essential to guarantee the protection of intra-SADC investments in times of strife or violence. The failure to include this provision suggests that lesser protection is given to intra-SADC investors than would be given to other investors under BITs.

\section{Bibliography}

\section{Literature}

Albath Trade and Energy

Albath L Trade and Energy: Investment in Gas and Electricity Sectors (Cameron May London 2004)

Alvarez Public International Law Regime

Alvarez JE The Public International Law Regime Governing International Investment (Hague Academy of International Law Hague 2011)

Bjorklund Yearbook on International Investment Law and Policy Bjorklund AK Yearbook on International Investment Law and Policy, 20132014 (Oxford University Press New York 2015)

Bjorklund and Reinisch International Investment Law Bjorklund AK and Reinisch A (eds) International Investment Law and Soft Law (Edward Elgar Cheltenham 2012) 
Bonnitcha Substantive Protection under Investment Treaties

Bonnitcha J Substantive Protection under Investment Treaties (Cambridge University Press Cambridge 2014)

Brown Commentaries on Selected Model Investment Treaties

Brown C (ed) Commentaries on Selected Model Investment Treaties (Oxford University Press Oxford 2013)

Caliskan Development of International Investment Law

Caliskan Y The Development of International Investment Law: Lessons from the OECD MAI Negotiations and their Application to a Possible Multilateral Agreement on Investment (Dissertation.com Florida 2008)

Collins Introduction to International Investment Law

Collins D An Introduction to International Investment Law (Cambridge University Press Cambridge 2016)

Desierto Public Policy in International Economic Law

Desierto DA Public Policy in International Economic Law: The ICESCR in Trade, Finance and Investment (Oxford University Press Oxford 2015)

Dimopoulos EU Foreign Investment Law

Dimopoulos A EU Foreign Investment Law (Oxford University New York Press 2011)

Dolzer and Schreuer Principles of International Investment Law

Dolzer R and Schreuer C Principles of International Investment Law $2^{\text {nd }}$ ed (Oxford University Press Oxford 2012)

Dunning and Gugler Foreign Direct Investment

Dunning $\mathrm{JH}$ and Gugler P (eds) Foreign Direct Investment, Location and Competitiveness vol 2 (Elsevier Amsterdam 2008)

Dupy, Francioni and Petersman Human Rights in International Investment Law

Dupy PM, Francioni F and Petersmann EU Human Rights in International Investment Law and Arbitration (Oxford University Press Oxford 2009)

Flodgren Corporate and Employment Perspectives

Flodgren B (ed) Corporate and Employment Perspectives in a Global Business Environment (Kluwer Law International AH Alphen 2006) 
Gazzini Interpretation of International Investment Treaties

Gazzini T Interpretation of International Investment Treaties (Bloomsbury London 2016)

Gazzini and Brabandere International Investment Law

Gazzini T and Brabandere E International Investment Law: The Sources of Rights and Obligations (Martinus Nijhoff Leiden 2012)

Grear and Kotzé Research Handbook on Human Rights and the Environment

Grear A and Kotzé J (eds) Research Handbook on Human Rights and the Environment (Edward Elgar Cheltenham 2015)

Gwynn Power in the International Investment Framework

Gwynn MA Power in the International Investment Framework (Springer London 2016)

Hackworth Digest of International Law

Hackworth G Digest of International Law vol 5 (Government Printing Office Washington 1943)

Hamilton et al Latin American Investment Protection

Hamilton JC et al Latin American Investment Protection: Comparative Perspectives on Laws, Treaties, and Disputes for Investors, States and Counsel (Martinus Nijhoff Leiden 2012)

Horn Arbitrating Foreign Investment Disputes

Horn N (ed) Arbitrating Foreign Investment Disputes (Kluwer Law International The Hague 2004)

Houde "Novel Features in Recent OECD Bilateral Investment Treaties" Houde MF "Novel Features in Recent OECD Bilateral Investment Treaties" in OECD International Investment Perspectives (OECD Paris 2006) 143181

Kläger "Fair and Equitable Treatment"

Kläger R "Fair and Equitable Treatment" in International Investment Law (Cambridge University Press Cambridge 2011)

Laos Foundations of Cultural Diplomacy

Laos NK Foundations of Cultural Diplomacy: Politics among Cultures and the Moral Autonomy of Man (Algora New York 2011) 
Laryea and Laeven Principles of Household Debt Restructuring

Laryea $\mathrm{T}$ and Laeven L Principles of Household Debt Restructuring (International Monetary Fund Washington DC 2009)

Leite 2016 Am U Int'l L Rev

Leite $S$ "The Fair and Equitable Treatment Standard: The Search for a Better Balance in International Investment Agreements" 2016 Am U Int'l L Rev 363-401

Lim Alternative Visions

Lim CL Alternative Visions of the International Law on Foreign Investment (Cambridge University Press Cambridge 2016)

Mallin Corporate Social Responsibility

Mallin CA (ed) Corporate Social Responsibility: A Case Study Approach (Edward Elgar Cheltenham 2009)

McGowan, Cornelissen and Nel Power, Wealth and Global Equity

McGowan PJ, Cornelissen S and Nel P Power, Wealth and Global Equity: An International Relations Textbook for Africa $3^{\text {rd }}$ ed (Juta Cape Town 2007)

Muchlinski Multinational Enterprises and the Law

Muchlinski P Multinational Enterprises and the Law (Oxford University Press Oxford 1995)

Muchlinksi, Ortino and Schreuer Oxford Handbook

Muchlinksi P, Ortino F and Schreuer C The Oxford Handbook of International Investment Law (Oxford University Press Oxford 2008)

Nde Fru International Law on Foreign Investments

Nde Fru V The International Law on Foreign Investments and Host-States in Sub-Saharan Africa: Cameroon, Nigeria, and Kenya (Transaction Piscataway 2011)

Ndlovhu 2011 LDD

Ndlovhu L "Following the NAFTA Star: SADC Land Reform and Investment Protection after the Campbell Litigation" 2011 LDD 59-89

Newcombe and Paradell Law and Practice of Investment Treaties Newcombe AP and Paradell L Law and Practice of Investment Treaties: Standards of Treatment (Kluwer Law International Alphen aan den Rijn 2009) 
Nhamo and Chekwoti Land Grabs in a Green Economy

Nhamo G and Chekwoti C (eds) Land Grabs in a Green Economy: Implications for Trade, Investment and Development Policies (Africa Institute of South Africa Pretoria 2014)

OECD International Regulatory Co-operation

Organisation for Economic Co-operation and Development International Regulatory Co-operation: Case Studies vol 1 (OECD Paris 2013)

OECD Investment Policy Reviews: Jordan 2013

Organisation for Economic Co-operation and Development $O E C D$ Investment Policy Reviews: Jordan 2013 (OECD Paris 2013)

OECD Investment Policy Reviews: Russian Federation 2006

Organisation for Economic Co-operation and Development OECD Investment Policy Reviews: Russian Federation 2006 Enhancing Policy Transparency (OECD Paris 2006)

Pillay Changing Nature of Corporate Social Responsibility

Pillay R The Changing Nature of Corporate Social Responsibility: CSR and Development - The Case of Mauritius (Routledge New York 2015)

Price 1993 Int'l Law

Price DM "An Overview of the NAFTA Investment Chapter: Substantive Rules and Investor-State Dispute Settlement" 1993 Int'l Law 727-736

Pryles Dispute Resolution in Asia

Pryles MC (ed) Dispute Resolution in Asia $3^{\text {rd }}$ ed (Kluwer Law International Alphen aan den Rijn 2006)

Reinisch Standards of Investment Protection

Reinisch A (ed) Standards of Investment Protection (Oxford University Press New York 2008)

Sacerdoti et al General Interests of Host States

Sacerdoti G et al (eds) General Interests of Host States in International Investment Law (Cambridge University Press Cambridge 2014)

Salacuse Law of Investment Treaties

Salacuse JW The Law of Investment Treaties $2^{\text {nd }}$ ed (Oxford University Press Oxford 2015) 
Sauvant Yearbook on International Investment Law and Policy

Sauvant KP (ed) Yearbook on International Investment Law and Policy 2011-2012 (Oxford University Press New York 2013)

Schill International Investment Law

Schill SW (ed) International Investment Law and Comparable Public Law (Oxford University Press Oxford 2010)

Skovgaard Poulsen Bounded Rationality and Economic Diplomacy

Skovgaard Poulsen LN Bounded Rationality and Economic Diplomacy: The Politics of Investment Treaties in Developing Countries (Cambridge University Press Cambridge 2015)

Solanes and Jouravlev Revisiting Privatisation

Solanes M and Jouravlev A Revisiting Privatisation, Foreign Investment, International Arbitration, and Water (United Nations Santiago 2007)

Sornarajah International Law on Foreign Investment Sornarajah M The International Law on Foreign Investment (Cambridge University Press New York 2004)

Steger Redesigning the World Trade Organization Steger DP (ed) Redesigning the World Trade Organization for the Twentyfirst Century (Wilfrid Laurier University Press Waterloo 2010)

Tabari Lex Petrolea and International Investment Law

Tabari NM Lex Petrolea and International Investment Law: Law and Practice in the Persian Gulf (Informa Law from Routledge Milton Park 2017)

Tanzi et al International Investment Law in Latin America

Tanzi A et al (eds) International Investment Law in Latin America: Problems and Prospects (Brill Leiden 2016)

Titi Right to Regulate in International Investment Law

Titi C The Right to Regulate in International Investment Law (Hart Zurich 2014)

Tudor Fair and Equitable Treatment Standard

Tudor I The Fair and Equitable Treatment Standard in the International Law of Foreign Investment (Oxford University Press Oxford 2008)

Van den Berg International Commercial Arbitration

Van den Berg AJ (ed) International Commercial Arbitration: Important Contemporary Questions (Kluwer Law International The Hague 2003) 
Van Duzer, Simons and Mayeda Integrating Sustainable Development Van Duzer JA, Simons P and Mayeda G Integrating Sustainable Development into International Investment Agreements: A Guide for Developing Country Negotiators (Commonwealth Secretariat London 2013)

Vandevelde 2013 LCLR

Vandevelde KJ "Rebalancing Through Exceptions" 2013 LCLR 449-459

Vandevelde US International Investment Agreements

Vandevelde KJ US International Investment Agreements (Oxford University Press New York 2009)

Viterbo International Economic Law and Monetary Issues

Viterbo A International Economic Law and Monetary Issues: Limitations to State Sovereignty and Dispute Settlement (Edward Elgar Cheltenham 2012)

Wellhausen Shield of Nationality

Wellhausen RL The Shield of Nationality: When Governments Break Contracts with Foreign Firms (Cambridge University Press New York 2015)

Woodbridge Next World War

Woodbridge RM The Next World War: Tribes, Cities, Nations and Ecological Decline (University of Toronto Press Toronto 2004)

\section{Case law}

$A D C$ v Hungary ICSID Case No ARB/03/16 of 2 October 2006

ADF v USA ICSID Case No ARB(AF)/00/1 of 9 January 2003

Asian Agricultural Products Ltd v Sri Lanka ICSID Case No ARB/87/3

Bernadus Henricus Funnekotter $v$ Republic of Zimbabwe ICSID Case No ARB/05/06

Bernhard von Pezold v Republic of Zimbabwe ICSID Case No ARB/1/15

CME v Czech Republic (UNCITRAL) 9 ICSID Reports 121 of 13 September 2001

Desarrollo de Santa Elena S.A. $v$ The Republic of Costa Rica ICSID Case No. ARB/96/1 of 17 February 2000

Germany v Poland (1928) PCIJ, Ser A, No 17 of 13 September 1928 
Maffezini v Spain ICSID Case No ARB/97/7

Mike Campbell (Pvt) Ltd $v$ Republic of Zimbabwe 2008 SADCT 2 of 28 November 2008

MTD v Chile ICSID Case No ARB/01/7 25 May 2004

Ocidental Petroleum v Ecuador ICSID Case No ARB06/11 of 5 October 2012

Piero Foresti, Laura de Carli v Republic of South Africa ICSID Case No $\mathrm{ARB}(\mathrm{AF}) / 07 / 1$

Pope and Talbot $v$ Canada, UNCITRAL

Railroad Development Corp v Guatemala ICSID Case No ARB/07/23

Siemens v Argentina ICSID Case No ARB/02/8 of 3 August 2004

Tecmed v Mexico ICSID Case No ARB (AF)/00/2 of 29 May 2003

The Loewen Group Inc, Raymond L Loewen v The United States of America ICSID Case No ARB(AF)/98/3 26 June 2003

Waste Management v United Mexican States ICSID Case No ARB(AF)/00/3 Yaung Chi Oo (YCO) Trading Pte Ltd $v$ Myanmar ASEAN ID Case No ARB/01/1 31 March 2003

\section{Legislation}

Broad-Based Black Economic Empowerment Act 53 of 2003 (South Africa) Constitution of the Republic of South Africa, 1996

Constitution of the Republic of Zimbabwe, 2013

Indigenisation and Economic Empowerment Act [Chapter 14: 30] (Zimbabwe)

Investment Promotion Act (GN 131 of 2009) (Ghana)

Mineral and Petroleum Resources Development Act 28 of 2002 (South Africa)

Procurement Act [Chapter 22: 14] (Zimbabwe) 
Protection of Investment Act 22 of 2015 (South Africa)

\section{Government publications}

Statutory Instrument 21 of 2010 in GG Extraordinary of 29 January 2010 (Zimbabwe)

Statutory Instrument 34 of 2011 in GG Extraordinary of 25 March 2011 (Zimbabwe)

Statutory Instrument 84 of 2011 in GG Extraordinary of 27 July 2011 (Zimbabwe)

Statutory Instrument 114 of 2011 in GG Extraordinary of 25 March 2011 (Zimbabwe)

Statutory Instrument 66 of 2013 in GG of 17 March 2013 (Zimbabwe)

\section{International instruments}

Agreement between the Government of the Republic of South Africa and the Government of the Republic of Zimbabwe for the Promotion and Reciprocal Protection of Investments (2009)

Agreement between the Government of the United Kingdom of Great Britain and Northern Ireland and the Government of the Kingdom of Swaziland for the Promotion and Protection of Investments (1995)

Agreement between the Republic of Colombia and the Swiss Confederation on the Promotion and Reciprocal Protection of Investments (2006)

Agreement between the Swiss Confederation and the Republic of Botswana on the Promotion and Reciprocal Protection of Investments (1998)

Agreement on Encouragement and Reciprocal Protection of Investments between the Republic of Zimbabwe and the Kingdom of the Netherlands (1996)

Agreement between the Government of the Republic of South Africa and the Government of the Republic of Zimbabwe for the Promotion and Reciprocal Protection of Investments (2009)

EU-Canada Comprehensive Economic Trade Agreement (2016)

Federal Republic of Germany and Lesotho Treaty Concerning the Encouragement and Reciprocal Protection of Investment (with Protocol) (1982)

Havana Charter of the International Trade Organisation (1948) 
International Centre for Settlement of Disputes Convention (1965)

Norway Model Bilateral Investment Treaty (2015)

North American Free Trade Agreement (1994)

Southern African Development Community Bilateral Investment Treaty (Template with Commentary) (2012)

Southern African Development Community Protocol on Finance and Investment (2006)

Southern African Development Community Agreement Amending Annex 1 (Co-operation on Investment) of the Protocol on Finance and Investment (2015)

Southern African Development Community Treaty (1992)

United Nations Convention on the Recognition and Enforcement of Foreign Arbitral Tribunal Awards (1958)

United States of America Model Bilateral Investment Treaty (2015)

\section{Internet sources}

Adeleke 2015 http://www.saiia.org.za/policy-insights/benchmarking-southafricas-foreign-direct-investment-policy

Adeleke F 2015 Benchmarking South Arica's Foreign Direct Investment Policy - SAllA Policy Insights 13 http://www.saiia.org.za/policyinsights/benchmarking-south-africas-foreign-direct-investment-policy accessed 1 August 2017

Bosman 2016 https://www.ekon.sun.ac.za/wpapers/2016/wp042016/wp04-2016.pdf

Bosman K 2016 South Africa: Trading International Investment for Policy Space https://www.ekon.sun.ac.za/wpapers/2016/wp042016/wp-04-2016. pdf accessed 1 June 2017.

Claypoole 2013 http://www.lexology.com/library/detail.aspx?g=e420a2710395-4751-ada5-dcb985104307

Claypoole C 2013 The SADC Protocol on Finance and Investment: An Underused Investment Protection Tool in Southern Africa http://www.lexology.com/library/detail.aspx?g=e420a271-0395-4751-ada5dcb985104307 accessed 26 November 2016 
EFILA $2015 \quad$ http://efila.org/wp-content/uploads/2015/05/EFILA_in_ response_to_the-criticism_of_ISDS_final_draft.pdf

European Federation for Investment Law and Arbitration 2015 A Response to the Criticism against ISDS http://efila.org/wp-content/ uploads/2015/05/EFILA_in_response_to_the-criticism_of_ISDS_final_draft .pdf accessed on 2 August 2017

Geldenhuys 2012 https://tradelawchambers.com/raxo-what-s-on/116-anew-sadc-tribunal

Geldenhuys R 2012 A New SADC Tribunal? https://tradelawchambers.com/ raxo-what-s-on/116-a-new-sadc-tribunal accessed 2 June 2017

Legum 2005 https://www.oecd.org/investment/internationalinvestment agreements/36370461.pdf

Legum B 2005 Defining an Investor: Who is entitled to Claim? https://www.oecd.org/investment/internationalinvestmentagreements/3637 0461.pdf accessed 1 June 2017

Nikièma 2012 http://www.iisd.org/pdf/2012/best_practice_indirect_ expropriation.pdf

Nikièma SH 2012 Best Practices: Indirect Expropriation http://www.iisd.org/pdf/2012/best_practice_indirect_expropriation.pdf accessed 1 August 2017

Trade and Investment Parliamentary Committee 2015 http://pmg-assets.s3website-eu-west-1.amazonaws.com/150916Summary.pdf

Trade and Investment Parliamentary Committee 2015 Summary of Submissions for the Promotion and Protection of Investment Bill (PPIB) [B18-2015] http://pmg-assets.s3-website-eu-west-1.amazonaws.com/ 150916Summary.pdf accessed 31 July 2017

PMG 2016 http://pmg.org.za/files/150922summary.pdf

Parliamentary Monitoring Group 2016 Summary of the Key Amendments to Annex 1 of the SADC Finance and Investment Protocol http://pmg.org.za/files/150922summary.pdf accessed 2 June 2017

Porterfield 2013 https://www.iisd.org/itn/2013/03/22/a-distinction-without-adifference-the-interpretation-of-fair-and-equitable-treatment-undercustomary-international-law-by-investment-tribunals/ Porterfield MW 2013 A Distinction Without a Difference? The Interpretation of Fair and Equitable Treatment under Customary International Law by Investment Tribunals https://www.iisd.org/itn/2013/03/22/a-distinctionwithout-a-difference-the-interpretation-of-fair-and-equitable-treatment- 
under-customary-international-law-by-investment-tribunals/ accessed 29 November 2016

Rosendorff and Shin 2012 https://wp.nyu.edu/faculty-rosendorff/wpcontent/uploads/sites/1510/2015/03/RosendorffShinAPSA2012.pdf

Rosendorff BP and Shin K 2012 Importing Transparency: The Political Economy of BITs and FDI Flows https://wp.nyu.edu/faculty-rosendorff/wpcontent/uploads/sites/1510/2015/03/RosendorffShinAPSA2012.pdf accessed 1 August 2017

Sabanogullari 2015 https://www.iisd.org/itn/2015/05/21/the-merits-andlimitations-of-general-exception-clauses-in-contemporary-investmenttreaty-practice/

Sabanogullari L 2015 The Merits and Limitations of the General Exception Clauses in Contemporary Investment Treaty Practice https://www.iisd.org/itn/2015/05/21/the-merits-and-limitations-of-generalexception-clauses-in-contemporary-investment-treaty-practice/ accessed 10 December 2016

SADC, GIZ and Finmark Trust 2011 http://www.finmark.org.za/sites//wpcon tent/uploads/pubs/Broch_FIP0312.pdf

SADC, GIZ and Finmark Trust 2011 Striving for Regional Integration: Baseline Study on the Implementation of the SADC Protocol on Finance and Investment http://www.finmark.org.za/sites//wpcontent/uploads/pubs/ Broch_FIP0312.pdf accessed 28 November 2016

Trade and Investment Parliamentary Committee 2015 http://pmg-assets.s3website-eu-west-1.amazonaws.com/150922Summary_of_Matrix.pdf Trade and Investment Parliamentary Committee 2015 Summary of Submissions for the Promotion and Protection of Investment Bill (PPIB) [B18-2015] http://pmg-assets.s3-website-eu-west-1.amazonaws.com/ 150922Summary_of_Matrix.pdf accessed 17 August 2017

UNCTAD 2007 http://unctad.org/en/docs/iteiia20065_en.pdf United Nations Conference on Trade and Development 2007 Bilateral Investment Treaties 1995 - 2006: Trends in Investment Rulemaking http://unctad.org/en/docs/iteiia20065_en.pdf accessed 1 June 2016 UNCTAD 2012 http://unctad.org/en/Docs/unctaddiaeia2011d5_en.pdf United Nations Conference on Trade and Development 2012 Fair and Equitable Treatment http://unctad.org/en/Docs/unctaddiaeia2011d5_en.pdf accessed 1 August 2017 
Woolfrey $2014 \quad$ https://www.tralac.org/discussions/article/5358-is-anoverhaul-of-the-sadc-protocol-on-finance-and-investment-imminent.html Woolfrey S 2014 Is an Overhaul of the SADC Protocol on Finance and Investment Imminent? https://www.tralac.org/discussions/article/5358-isan-overhaul-of-the-sadc-protocol-on-finance-and-investmentimminent.html accessed 26 November 2016

\section{List of Abbreviations}

Am U Int'I L Rev

BEE Act

BITs

CCIA

CETA

CSR

EFILA

FTAs

GATS

GATT

ICSID

IEEA

IIAs

Int'I Law

ISDS

ITO

LCLR

LDD

MFN

NAFTA

OECD

PMG

RTA

RTIAs
American University International Law Review

Broad-Based Black Economic

Empowerment Act

Bilateral Investment Treaties

Common Investment Area Agreement

EU-Canada Comprehensive Economic

Trade Agreement

Corporate Social Responsibility

European Federation for Investment Law and

Arbitration

Free Trade Agreements

General Agreement in Trade in Goods and

Services

General Agreement of Trade and Tariffs

International Centre for Settlement of Disputes

Indigenisation and Economic Empowerment Act

International Investment Agreements

The International Lawyer

Investor-State Dispute Settlement

International Trade Organisation

Lewis and Clark Law Review

Law, Democracy and Development

Most Favoured Nation

North American Free Trade Area

Organisation for Economic Co-operation and Development

Parliamentary Monitoring Group

Regional Trade Agreement

Regional Trade and Investment Agreements 


$\begin{array}{ll}\text { SADC } & \begin{array}{l}\text { Southern African Development Community } \\ \text { SADC FIP }\end{array} \\ & \text { Southern African Development Community } \\ & \text { Protocol on Finance and Investment } \\ \text { SADC Model BIT } & \text { Southern African Development Community } \\ & \text { Model Bilateral Investment Treaty } \\ & \text { Southern African Development Community } \\ \text { SADC Treaty } & \text { Treaty } \\ \text { UN } & \text { United Nations } \\ \text { UNCITRAL } & \text { United Nations Commission on International } \\ & \text { Trade Law } \\ \text { UNCTAD } & \text { United Nations Conference on Trade and } \\ & \text { Development } \\ \text { WTO } & \text { World Trade Organisation } \\ \text { WW2 } & \text { Second World War }\end{array}$

